\title{
HPLC DETERMINATION OF ETOPOSIDE IN INJECTABLE DOSAGE FORMS
}

\author{
M. MUNAWAR HAYAT ${ }^{1}$, MUHAMMAD ASHRAF², NISAR-UR-REHMAN ${ }^{3}$, \\ FAIZ-UL-HASSAN NASIM ${ }^{2}$ IRSHAD AHMAD ${ }^{l}$, JAMEEL RAHMAN ${ }^{4}$, MUHAMMAD SALEEM ${ }^{4}$ AND \\ M. ZUBAIR MALIK ${ }^{1}$
}

\begin{abstract}
${ }^{1}$ Department of Pharmacy, ${ }^{2}$ Department of Biochemistry \& Biotechnology, The Islamia University of Bahawalpur, Bahawalpur, Pakistan. ${ }^{3}$ Department of Pharmacy, COMSATS Institute of information Technology, Abbottabad Campus, Abbottobad. Pakistan.
\end{abstract}

${ }^{2}$ Department of Chemistry, The Islamia University of Bahawalpur, Bahawalpur, Pakistan.

(Received: January 28, 2011 - Accepted: May 5, 2011)

\begin{abstract}
1. The present study describes a direct and an alternative HPLC method for the determination of etoposide in injectable dosage forms. Etoposide, an antineoplastic drug, was eluted through $C_{18}$ ODS Hypersil column of $250 \times 4.6 \mathrm{~mm}$ id with $5 \mu \mathrm{m}$ particle size using simple mobile phase of methanol: water (1:1, $\mathrm{v} / \mathrm{v}$ ) at a flow rate of $1.0 \mathrm{~mL} \mathrm{~min}^{-1}$ and detected at $204 \mathrm{~nm}$. The limit of detection of etoposide was $0.03 \mu \mathrm{g} \mathrm{mL} \mathrm{m}^{-1}$. The proposed method was found linear in the range of $0.25 \mu \mathrm{g} \mathrm{mL} \mathrm{m}^{-1}$ to $62.5 \mu \mathrm{g} \mathrm{mL}-1$ and $\mathrm{CV}$ was $1.3 \%$ at $0.25 \mu \mathrm{g} \mathrm{mL}^{-1}, 0.48 \%$ at $3.90 \mu \mathrm{g} \mathrm{mL}^{-1}$ and $0.13 \%$ at $62.5 \mu \mathrm{g} \mathrm{mL}$. The accuracy of the developed method for two injectable dosage forms was 99.4 and $99.7 \%$ with RSD of $0.3 \%$. The validation results and statistical data demonstrate that the method is simple, cost effective, reproducible and suitable in quality analysis of the active ingredient and dosage form.
\end{abstract}

Keywords: Etoposide, HPLC, injectable dosage forms, nefopam.

\section{INTRODUCTION}

Etoposide [(4'-demethyl-epipodophylotoxin 9-[4,6-O- $(R)$-ethylidene$\beta$-D-glucopyranoside] is a semi-synthetic derivative of epipodophyllotoxins (figure 1) obtained from plant Mandragora officianarum. It was introduced in clinical practice in early 1970's and now used in a large number of human malignant diseases including leukemia, lymphomas and lung cancer [1]. It inhibits topoisomerase II activity, the enzyme is involved in uncoiling DNA, thus affecting its repair and replication [2]. Both intravenous and oral dosage forms are used. It is often given in combination with other antineoplastic drugs of different mode of action like cisplatin [3-4].

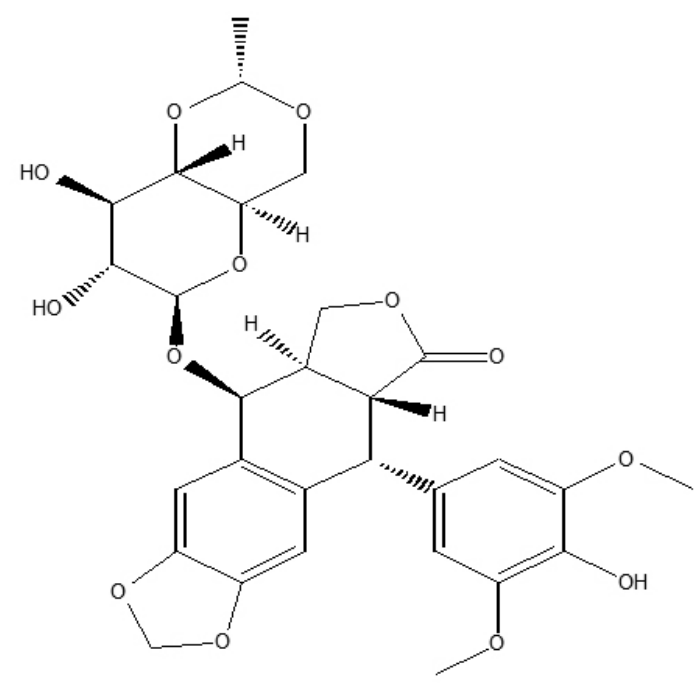

Figure 1: Structure of etoposide (4'-demethyl-epipodophylotoxin 9-[4,6-O- $(R)$-ethylidene- $\beta$-D-glucopyranoside]).

Liquid chromatography is a sensitive and accurate method used for quantitative analysis of drugs. Several methods for the determination of etoposide include HPLC with UV detection [5-8], fluorescence detection [9], and electrochemical detection [10-11]. It has also been determined by LC-MS method [12-13] and ELISA method [14]. These previously published methods use mixture of expensive organic solvents or demand costly equipment [11-13]. There was a need to develop and validate a simple and cost effective HPLC method for the determination of etoposide. The present work therefore is an alternative to previously published work and is simple and cost effective using one organic solvent as mobile phase.

\section{EXPERIMENTAL}

Chemicals and materials

Etoposide was kindly supplied by Pharmedic Laboratories Pvt. Ltd. Lahore, (Pakistan) with $99.64 \%$ purity. Methanol and $\mathrm{HCl}$ were of HPLC grade from Merck, Germany. The column $\mathrm{C}_{18}$ (ODS Hypersil) was purchased from Thermo Electron Corporation, UK. Nefopam (internal standard) is of analytical grade.

Instrumentation and HPLC conditions

A Sykam series chromatographic system consisting of solvent delivery system (S- 2100), Injector value Bracket (S 5111) and UV / Vis detector (S3210 ) with column $C_{18}$ ODS Hypersil column having dimensions $250 \times 4.6$ $\mathrm{mm}$ with $5 \mu \mathrm{m}$ particle size was used. The detection was set at $204 \mathrm{~nm}$. The mobile phase consisted of methanol and water $(1: 1)$ and $\mathrm{pH}$ was maintained at 4.20 with $0.2 \mathrm{~N} \mathrm{HCl}$. The flow rate was maintained at $1.0 \mathrm{~mL} \mathrm{~min}^{-1}$. The analyte was injected into a loop of $20 \mu \mathrm{l}$. The system was attached with a computer soft ware (Clarity ver. 2.5) to analyze and calculate data.

Preparation of mobile phase

Mobile phase was prepared by mixing HPLC grade methanol with double distilled filtered water (1:1) and contents filtered through $0.45 \mu \mathrm{m}$ membrane filter (Sartorius Stedim, Germany). The pH was adjusted to 4.20 with $0.2-\mathrm{N}$ $\mathrm{HCl}$. Mobile phase was used after degassing.

Standard preparation

Stock solutions $\left(1.0 \mathrm{mg} \mathrm{mL}^{-1}\right)$ each of etoposide and internal standard nefopam were prepared in the mobile phase. A standard solution of nefopam, at fixed concentration of $500 \mu \mathrm{g} \mathrm{mL} \mathrm{m}^{-1}$ was prepared by dilution of stock solution. Further dilutions of etoposide were made up to $0.03 \mu \mathrm{g} \mathrm{mL}-1$. Fresh solutions were prepared daily, filtered, and degassed by sonication.

Sample preparation

The samples were prepared by dissolving two injectable brands of etoposide in mobile phase to yield $1.0 \mathrm{mg} \mathrm{mL}^{-1}$ solution and further dilutions were made with mobile phase for analysis.

\section{RESULTS AND DISCUSSION}

Analytical method development

In the HPLC method development process, various systems of mobile phase with several combinations were tested. Table 1 shows the various mobile phases used during the development of the proposed method. Finally, methanol: water (1:1) at $\mathrm{pH} 4.20$ was found to be the most suitable at flow rate of $1.0 \mathrm{~mL} \mathrm{~min}^{-1}$. Run time of every elution was $10 \mathrm{~min}$. Nefopam was selected as an internal standard because it was found stable under the experimental conditions, not reactive with the drug and eluted first with reasonable retention time.

Peak identification

The peak of etoposide was identified by comparison of retention times of sample and standard solution, the increase or decrease in size of the peak 
with change of concentration of standard solution was determined. During application of this method, the etoposide was eluted at $6.6 \mathrm{~min}$. Nefopam also co-eluted at $1.76 \mathrm{~min}$ as an internal standard. A representative chromatogram is given in figure 2 .

Table 1: Different mobile phases used during the HPLC method development proces.

\begin{tabular}{|l|c|c|}
\hline Mobile phase & Ratio & $\mathrm{pH}$ \\
\hline methanol: $\mathrm{KH}_{2} \mathrm{PO}_{4}$ & $40: 60$ & 7.0 \\
\hline $\begin{array}{l}\text { methanol: water: acetonitrile: } \\
\text { ammonium acetate }(10 \mu \mathrm{M})\end{array}$ & $44: 30: 25: 1$ & 5.5 \\
\hline methanol: water: acetonitrile & $45: 30: 25$ & $5.5-6.5$ \\
\hline methanol: water: acetonitrile & $44: 30: 25$ & $5.2-8.5$ \\
\hline methanol: water: acetonitrile & $50: 33: 17$ & 5.5 \\
\hline methanol: water: acetonitrile & $35: 40: 25$ & $3.5-7.2$ \\
\hline methanol: water: acetonitrile & $40: 35: 25$ & $3.5-5.5$ \\
\hline methanol: water & $50: 50$ & $3.5-5.5$ \\
\hline
\end{tabular}

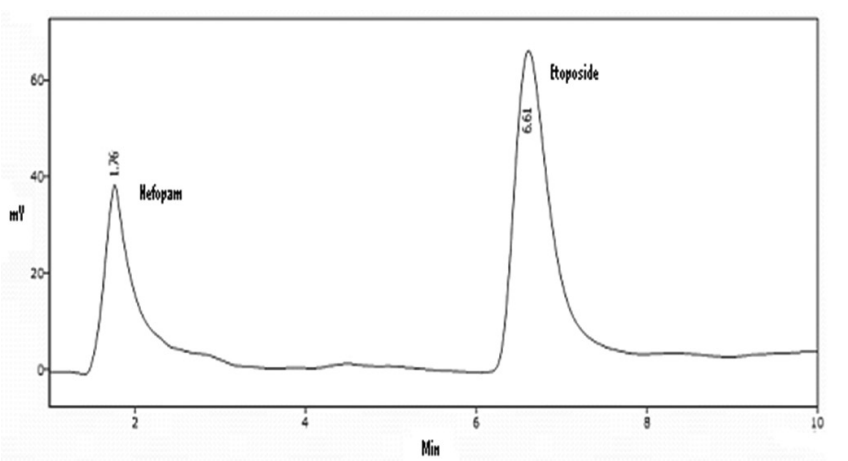

Figure 2: A representative chromatogram of etoposide and nefopam.

Method validation

Following parameters were evaluated step by step to ensure the testing of significant method characteristics according to good analytical practice guidelines.

Linearity and range

The standard stock solution of etoposide was diluted with mobile phase to prepare a set of solutions of different concentrations ranging from 0.25 to $62.50 \mu \mathrm{g} \mathrm{mL}^{-1}$ (table 2). Each drug concentrations was run in triplicates and data was plotted to calculate the parameters of standard curve. The values of slope, intercept and r-square for etoposide were 63.565, 4.608 and 0.9982, respectively. The values of these parameters were found to be consistent with FDA guidelines of method validation.

Table 2: Standard curve parameters for etoposide.

\begin{tabular}{|c|c|c|c|}
\hline Curve code & Slope & Intercept & r-square \\
\hline Batch-01 & 63.565 & 4.608 & 0.998 \\
\hline Batch-02 & 62.067 & 5.901 & 0.995 \\
\hline Batch-03 & 64.816 & 5.511 & 0.993 \\
\hline Mean & 63.5 & NA & 0.995 \\
\hline S.D. & 1.4 & NA & 0.0025 \\
\hline $\mathrm{N}$ & 3 & 3 & 3 \\
\hline$\% \mathrm{CV}$ & 2.2 & NA & 0.2528 \\
\hline
\end{tabular}

\section{Accuracy}

The accuracy of an analytical method expresses the closeness of test results with the mean value. Accuracy was determined by selecting low, medium and high concentrations of etoposide in triplicate. The mean values (low, medium and high) of accuracy for bulk etoposide were $99.16 \%, 99.74 \%$ and $99.78 \%$, respectively (table 3 ).

Precision

The precision of this analytical method was performed by repeating for three different days. The CV within-batch for low, medium and high concentrations were $2.1095 \%, 0.9413 \%$ and between batches were $1.2506 \%$,
$0.4809 \%$ and $0.1347 \%$, respectively, which are less than $3 \%$ which is within range of FDA guidelines (table 3-4).

Table 3: Data of between-batches precision and accuracy for etoposide solution of three batches.

\begin{tabular}{|c|c|c|c|}
\hline Curve code & Low Conc.(LC) & $\begin{array}{l}\text { Medium Conc. } \\
\text { (MC) }\end{array}$ & $\begin{array}{c}\text { High Conc. } \\
\text { (HC) }\end{array}$ \\
\hline & $\mu \mathrm{g} \mathrm{mL}^{-1}$ & $\mu \mathrm{g} \mathrm{mL}^{-1}$ & $\mu \mathrm{g} \mathrm{mL} L^{-1}$ \\
\hline \multirow[t]{3}{*}{ Batch-01 } & 0.251 & 3.91 & 62.42 \\
\hline & 0.249 & 3.89 & 62.39 \\
\hline & 0.248 & 3.90 & 62.23 \\
\hline \multirow[t]{3}{*}{ Batch-02 } & 0.251 & 3.88 & 62.45 \\
\hline & 0.246 & 3.91 & 62.37 \\
\hline & 0.241 & 3.87 & 62.46 \\
\hline \multirow[t]{3}{*}{ Batch-03 } & 0.247 & 3.88 & 62.31 \\
\hline & 0.248 & 3.86 & 62.41 \\
\hline & 0.250 & 3.91 & 62.25 \\
\hline Mean & 0.248 & 3.890 & 62.366 \\
\hline $\mathrm{SD}$ & 0.0031 & 0.0187 & 0.0840 \\
\hline $\mathrm{N}$ & 9 & 9 & 9 \\
\hline nominal & 0.25 & 3.90 & 62.50 \\
\hline$\% \mathrm{CV}$ & 1.2506 & 0.4809 & 0.1347 \\
\hline$\%$ accuracy & 99.16 & 99.74 & 99.78 \\
\hline
\end{tabular}

Table 4: Data of within-batch precision and accuracy for etoposide solution of batch-01.

\begin{tabular}{|c|c|c|c|}
\hline Curve code & $\mathrm{LC}$ & $\mathrm{MC}$ & $\mathrm{HC}$ \\
\hline & $\mu \mathrm{g} \mathrm{mL} L^{-1}$ & $\mu \mathrm{g} \mathrm{mL^{-1 }}$ & $\mu \mathrm{g} \mathrm{mL} L^{-1}$ \\
\hline 01 & 0.244 & 3.86 & 62.25 \\
\hline 02 & 0.246 & 3.81 & 62.38 \\
\hline 03 & 0.241 & 3.88 & 62.21 \\
\hline 04 & 0.242 & 3.81 & 62.41 \\
\hline 05 & 0.249 & 3.89 & 62.33 \\
\hline 06 & 0.255 & 3.82 & 62.42 \\
\hline Mean & 0.2462 & 3.8450 & 62.3333 \\
\hline SD & 0.0052 & 0.0362 & 0.0869 \\
\hline $\mathrm{N}$ & 6 & 6 & 6 \\
\hline Nominal & 0.25 & 3.90 & 62.50 \\
\hline$\% \mathrm{CV}$ & 2.1095 & 0.9413 & 0.1394 \\
\hline \%Accuracy & 98.47 & 98.59 & 99.73 \\
\hline
\end{tabular}

Stability and sensitivity

LOD (limit of detection) of etoposide was determined directly by serial dilution method and was found $0.03 \mu \mathrm{g} \mathrm{mL}^{-1}$. LOQ of etoposide was 0.250 $\mu \mathrm{g} \mathrm{mL}^{-1}$. LOD and LOQ (limit of quantification) values were determined with suitable accuracy and precision between batches and within batches and data is given in table 2-3. Bench top stability method was employed in stability studies of etoposide. The drug at two different concentrations was studied in triplicate with an interval of 2 hours till 6 hours as given in table 5. Data shows that the drug solution was stable within the experimental conditions of the developed method as depicted by $\mathrm{CV}(<3 \%)$.

\section{Robustness}

The method was found robust under varied conditions of flow rate $( \pm 0.03$

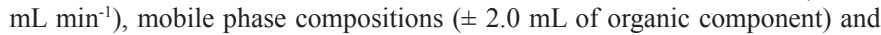
wavelength $( \pm 5 \mathrm{~nm})$ since no marked changes were observed in the elution profiles (data not shown).

\section{APPLICATIONS OF METHOD}

The developed method has an importance in the quality control and quality assurance of etoposide formulations during manufacturing in industry as well as monitoring the quality of different brands of etoposide formulations especially the injectables at drug testing laboratories or other regulatory agencies. This method is recommended for industrial analysis of etoposide. The application of this method is clearly demonstrated in table 6 which exhibits the quantitative analysis of two different injectable formulations of etoposide available in the market. 
Table 5: Bench top stability studies of etoposide solution.

\begin{tabular}{|c|c|c|c|c|c|c|c|c|}
\hline & \multicolumn{2}{|c|}{$0 \mathrm{~h}$} & \multicolumn{2}{c|}{$2 \mathrm{~h}$} & \multicolumn{2}{c|}{$4 \mathrm{~h}$} & \multicolumn{2}{c|}{$6 \mathrm{~h}$} \\
\hline & $\mathrm{LC}$ & $\mathrm{HC}$ & $\mathrm{LC}$ & $\mathrm{HC}$ & $\mathrm{LC}$ & $\mathrm{HC}$ & $\mathrm{LC}$ & $\mathrm{HC}$ \\
\hline \multirow{2}{*}{ Conc. } & $\mu \mathrm{g} \mathrm{mL}-1$ & $\mu \mathrm{g} \mathrm{mL}^{-1}$ & $\mu \mathrm{g} \mathrm{mL}^{-1}$ & $\mu \mathrm{g} \mathrm{mL}^{-1}$ & $\mu \mathrm{g} \mathrm{mL}^{-1}$ & $\mu \mathrm{g} \mathrm{mL}^{-1}$ & $\mu \mathrm{g} \mathrm{mL}^{-1}$ & $\mu \mathrm{g} \mathrm{mL}^{-1}$ \\
\hline & 0.259 & 62.521 & 0.251 & 62.512 & 0.246 & 62.504 & 0.242 & 62.501 \\
\cline { 2 - 10 } & 0.253 & 62.509 & 0.249 & 62.502 & 0.247 & 62.498 & 0.244 & 62.491 \\
\cline { 2 - 10 } & 0.257 & 62.567 & 0.255 & 62.557 & 0.252 & 62.551 & 0.249 & 62.548 \\
\hline Mean & 0.256 & 62.532 & 0.252 & 62.524 & 0.248 & 62.518 & 0.245 & 62.496 \\
\hline SD & 0.0031 & 0.0306 & 0.0031 & 0.0293 & 0.0032 & 0.0290 & 0.0036 & 0.0071 \\
\hline $\mathrm{N}$ & 3 & 3 & 3 & 3 & 3 & 3 & 3 & 2 \\
\hline \%CV & 1.1918 & 0.0490 & 1.2139 & 0.0469 & 1.2944 & 0.0464 & 1.4717 & 0.0113 \\
\hline Nominal & 0.250 & 62.5 & 0.250 & 62.5 & 0.250 & 62.5 & 0.250 & 62.5 \\
\hline
\end{tabular}

Table 6: Percent recovery of etoposide by forecast formula $(y=a+b x)$.

\begin{tabular}{|c|c|c|c|c|}
\hline $\begin{array}{c}\text { Serial } \\
\text { No. }\end{array}$ & Sample & Experiments & $\begin{array}{c}\text { Etoposide } \\
\text { quantity found } \\
\left.(\mu \mathrm{g} \mathrm{mL})^{-1}\right)\end{array}$ & Accuracy (\%) \\
\hline 1 & \multirow{10}{*}{$\begin{array}{l}\text { Brand } 1 \\
\text { (Med) }\end{array}$} & 1 & 998.19 & 99.8 \\
\hline 2 & & 2 & 995.21 & 99.5 \\
\hline 3 & & 3 & 987.43 & 98.7 \\
\hline 4 & & 4 & 996.12 & 99.6 \\
\hline 5 & & 5 & 995.26 & 99.5 \\
\hline 6 & & 6 & 992.71 & 99.2 \\
\hline Mean & & & 994.15 & 99.4 \\
\hline SD & & & 3.73 & - \\
\hline RSD & & & 0.37 & - \\
\hline $\mathrm{N}$ & & & 6 & 6 \\
\hline 1 & \multirow{10}{*}{$\begin{array}{c}\text { Brand } 2 \\
(\mathrm{CCL})\end{array}$} & 1 & 1003.24 & 100.3 \\
\hline 2 & & 2 & 997.98 & 99.7 \\
\hline 3 & & 3 & 995.32 & 99.5 \\
\hline 4 & & 4 & 993.01 & 99.3 \\
\hline 5 & & 5 & 997.95 & 99.7 \\
\hline 6 & & 6 & 998.85 & 99.8 \\
\hline Mean & & & 997.72 & 99.7 \\
\hline SD & & & 3.32 & - \\
\hline RSD & & & 0.33 & - \\
\hline $\mathrm{N}$ & & & 6 & 6 \\
\hline
\end{tabular}

CONCLUSIONS

The developed method is simple, cost effective, accurate and an alternative to other methods. The proposed method is suitable for the analysis of active ingredient as well as injectable dosage form of etoposide. It has short analysis time, low limit of detection $\left(0.03 \mu \mathrm{g} \mathrm{mL}^{-1}\right)$, with nefopam used as new internal standard and a simple mobile phase with one organic component. The accuracy of the developed method was $99.4 \%$ and $99.7 \%$ with RSD of $0.3 \%$. which was within the limits of FDA guidelines.

\section{REFERENCES}

1. P. J. Creaven, Cancer Chemother. Pharmacol. 7, 133, (1982).

2. J. D. Loike, S. B. Horwitz, Biochemistry. 15, 5443, (1976).

3. R. E. Durand, J. H. Goldie, Cancer Treat. Rep. 71, 673, (1987).

4. F. Kanzawa, K. Nishio, K. Fukuoka, M. Fukuda, Kunimotot, N. Saijo, Int. J. Cancer. 71, 311, (1997).

5. R. J. Strife, I. Jardine, M. J. Colvin, Journal of Chromatography. 182, 211, (1980).

6. R. H. Marla, T. M. Ludden, J. Pharm. Sci. 75, 815, (1986).

7. M. Snehalatha, B. Girish, K. Venugopal, R. N. Saha, Indian Journal Pharm. Educ. Res. 41 (4), 347, (2007).

8. United States Pharmacopia, Asian Edition, 2, 2106-07 (2007).

9. R. J. Strife, I. Jardine, M. J. Colvin, Journal of Chromatography. 224, $168,(1981)$

10. J. A. Sinkule, W. E. Evans, J. Pharm. Sci. 73, 164, (1984).

11. G. F. Duncan, R.H. Farmen, H. S. Movahhed, K. A. Pittman, Journal of Chromatography. 380, 357, (1986).

12. C.L. Chen, F. M. Uckun, J. Chromatogr. B Biomed. Sci. Appl. 744 (1), 91, (2000).

13. H. Danigel, K. H. Pfluger, Cancer Chemother. Pharmacol. 15 (2), 121, (1985).

14. H. P. Hennebery, G. W. Aherne, V. Marks, Journal Immunological. Methods. 107, 205, (1988). 